\title{
Participation of Household Women in Undertaking Plant Health Management Practices in Home Gardens
}

\author{
Vandana Kumari*
}

\begin{abstract}
Women in the agricultural sector in India, particularly in Bihar face many socio-economic, educational and legal obstacles in realizing benefits of their efforts. This study assessed the role of women in untertaking plant health management practices in home gardens. One hundred households were interviewed and data were analyzed. The study indicated that decisions related to vegetable production and marketing within home gardens were mainly taken by women while the decisions on cereal and pulse crop production, management and utilization were made mainly by men. Men were the main decision makers in the management and utilization of cash crops that grow in the home garden. From the surveyed households, women were main decision makers for the management, consumption and marketing of fruit plants. In livestock production and management men were responsible for making decisions in large animals like cows while women had very little contribution on deciding about large ruminants. It was found that labor-intensive activities like land preparation, planting activities and marketing of products were mainly done by men while seed preservation, manuring, weeding and storage of produce were mainly done by women. The average time women spend in the home garden was six to eight hour/week while men spend four to five hours a week. Policies and strategies need to be developed to enhance the benefits of home gardens to both men and women.
\end{abstract}

Keywords: Decision; Family; Home garden; Income; Plant Health; Men; Women; Bihar

\section{INRODUCTION}

Home gardening is a system of planting of fruit trees along with vegetables and ornamental plants in the premises of the house for multi-purposes. It includes a combination of methods of cultivation, landscaping and other techniques. These provide fresh fruits, vegetables and flowers throughout the year. However, home gardens are often overlooked by scientists and development agents because of their small size, apparent insignificance, and unclear perception by many people as individual household subsistence mechanisms. (Bunderson et al. 1990).

\footnotetext{
*Post Graduate Department of Home Science, MDDM College, Muzaffarpur 842002 (BRA Bihar University, Muzaffarpur), Bihar, India
}

Received : 01-08-2020; Accepted : 29-03-2021 
The participation of women in different activities of home garden maintenance is variable. According to Ranjan and Hedija (2004) the major portion of women's labor force in the production system is invested in weeding, harvesting, household animal care, marketing, post-harvest handling, etc. Harrowing and weeding, in particular, are considered as women's activities. Women are also active in livestock production. Their traditional role of housekeeping has been extended to collect firewood, fodder, and working on farms. In addition to their active engagement in agriculture and livestock production including home garden, women are responsible for all household tasks (Abebe and Mulu, 2017).

In most families, men and women differ in the activities they undertake, in access and control over resources, and in participation in decision making (Khanal and Khanal, 2016). The division of labor and decision making possibilities of women in home garden management such as digging hole, pruning, watering, weeding, fencing, species selection, seed selection, storage techniques, pest control techniques and their contribution on forest conservation are not well studied.

Therefore, this study aimed at uncovering the role of women in the management and control of home garden practices. The outcome of the study will be used in formulating future policies and strategies at the local level to empower women and make them beneficiaries of their labor. It will as well be used to have a better understanding of the kind of training which is required for women in the area.
The general objective of this study is to analyze the different roles of women in home garden management and utilization in Jamui district of Bihar with emphasis on the kind of tasks performed by women in agricultural production, the time spent by women in these tasks in the villages and to examine the relationship of women's income their role in decision making.

\section{METHODOLOGY}

The study area, Jamui is a district among 38 districts of Bihar state, India. Agriculture is the mainstay of the economy. The main products are food grains, pulses, jackfruit, Mahua, etc. Jamui is one of the prominent manufacturers of Bidi \& cement, iron \& steel, salt, sugar, cotton \& woolen textiles, kerosene oil, etc. Prominent crops are rice, wheat, maize, onion, jackfruit and mahua.

\section{Sampling Method}

In the present study, a multi stage sampling technique was employed. The first stage was classification of the villages based on intensity of home garden management. Three home garden agroforestry systems practicing villages were selected out of nine randomly using lottery system. The three selected villages were Kewal, Khaira and Sikandra. In the second stage before selecting households to be included in the sample, home garden agroforestry system practicing households of each selected village were collected from development agents. Five key informants from each village were purposively selected based on their age, knowledge about home garden and social position. These key 
informants defined wealth groups of residents into three categories as poor, medium, and rich following the criteria of farm size they own, amount of annual income obtained, number of livestock they hold and the labor involved in agriculture. Based on the key informants' criteria, households were selected.

\section{Data collection}

Data were collected from primary and secondary sources. Primary data were collected from sample households and key informants. Data were collected by using questionnaires and farm inventory. Secondary sources refer to information that was collected from the District offices of agriculture. These gave information on the general land use of the areas, the major crops, marketing and consumption patterns, etc., and the challenges faced in agriculture.

\section{Data analysis}

The quantitative data that were obtained through survey were analyzed by means of SPSS (Statistical package for social sciences) version 16. Statistical analysis tools including frequency, percentage and mean comparison were used to analyze quantitative data.

\section{FINDINGS AND DISCUSSION}

\section{Profile of respondents}

From the selected households, 56\% male and $44 \%$ females were observed in the study. About $42.1 \%$ of respondents were of the age group of $28-45$ years.

The occupational analysis of respondents showed that most of the women (about $60 \%$ ) were engaged only in household activities. Approximately $40 \%$ of the women were engaged in both household maintenance and income-generating activities (i.e., poultry rearing, vegetable cultivation, sewing, fruit species cultivation). According to the respondents, agriculture was the main source of income for most households, while day labor (both agricultural and nonagricultural wage work, e.g., in bidi making) was the next most important source of primary income. Secondary sources of household income included agriculture, poultry rearing and trade. The study further revealed that only $25 \%$ of women earned some money through wages, while the rest of the women did not earn money independently of their husbands and families. Among those women who did earn money, the majority of them earned it from vegetable cultivation (28\%).

Home garden is a common agroforestry practice in Jamui district. Nearly $60 \%$ farmers are practicing home garden model very close to home. The average size of the home gardens was $420 \mathrm{sq} \mathrm{m}$. Approximately 54 species had been recorded in a home garden.

The present study indicated that decisions related to vegetable production and marketing within home garden was mainly taken up by women. Bajaracharya (1994) reported that in vegetable production, women take $90 \%$ of decisions, whereas in fruit production men make most decisions. The study indicated (Table 1) that the decisions on cereal and pulse production, management 
Participation of Household Women in Undertaking Plant Health Management Practices in Home Gardens

Table 1.

Decision making of Household members in Different Products of Home Garden (N=100)

\begin{tabular}{|c|l|c|c|c|}
\hline Sl. No. & \multicolumn{1}{|c|}{ Type } & Men (\%) & Women (\%) & Both (\%) \\
\hline \multicolumn{5}{|c|}{ Crops } \\
\hline 1. & Vegetables & 14 & 71 & 15 \\
\hline 2. & Root crops & 25 & 40 & 35 \\
\hline 3. & Cereals \& Pulses & 82 & 2 & 16 \\
\hline 4. & Cash crops & 59 & 20 & 21 \\
\hline 5. & Fooder trees & 80 & 12 & 8 \\
\hline 6. & Fruits & 20 & 73 & 7 \\
\hline 7. & Tree production & 95 & 0 & 5 \\
\hline \multicolumn{5}{|c|}{ Livestock production } \\
\hline 8. & Large ruminants & 70 & 13 & 17 \\
\hline 9. & Small ruminants & 22 & 41 & 37 \\
\hline
\end{tabular}

and utilization were made mainly by men (82\%). Men were the main decision makers in the management and utilization of cash crops that grow in the home garden. Women (73\%) were the main decision makers for the management, consumption and marketing of fruit plants. The result indicated that men were deciders on trees planted in and around home garden. Because of the differential access to and control of land, women may not have control over tree planting and management. In livestock production and management, men were responsible in making decisions in large animals like cows (70\%) and women had very little contribution on deciding about large ruminants. On the other hand, women were responsible in making decisions in poultry production (41\%) than other types of livestock.
Men participate in land preparation for all types of production in home garden (Table 2). This might be because land preparation is an energy draining exercise that is better handled by men. The result is in agreement with FAO (2000, 2003) who reported that in crop production it is usually the men who plough the crop fields while the women do the majority of the other work including fertilizer \& pesticide application and harvesting. Seed preservation was handled by both men and women. For vegetables it was $100 \%$ done by women and $32 \%$ by men, while for cereals it was $100 \%$ by men and $78 \%$ by women. Planting was mainly the responsibility of men because of the cultural division of labour. However, the wives did the planting activity for vegetables and fruit tree seedlings because the area of land preparation of vegetable is small and intensity of land preparation was low. Application of 
Table 2.

Gender Division of Labour for Major Crops ( $\mathrm{N}=100$ )

\begin{tabular}{|c|l|c|c|c|c|c|c|c|c|c|c|}
\hline \multirow{2}{*}{$\begin{array}{c}\text { Sl. } \\
\text { No. }\end{array}$} & \multirow{2}{*}{ Activities } & \multicolumn{2}{|c|}{ Vegetables } & \multicolumn{2}{c|}{ Root crops } & \multicolumn{2}{c|}{$\begin{array}{c}\text { Cereals \& } \\
\text { Pulses }\end{array}$} & \multicolumn{2}{c|}{ Cash crops } & \multicolumn{2}{c|}{ Fruits } \\
\cline { 3 - 14 } & & M & F & M & F & M & F & M & F & M & F \\
\hline 1. & Land preparation & 100 & 33 & 100 & 0 & 100 & 12 & 100 & 54 & 100 & 57 \\
\hline 2. & Seed preservation & 32 & 100 & 21 & 67 & 100 & 78 & 15 & 88 & 55 & 33 \\
\hline 3. & Planting & 50 & 50 & 100 & 55 & 78 & 22 & 50 & 50 & 84 & 92 \\
\hline 4. & Manuring & 0 & 100 & 93 & 21 & 98 & 80 & 98 & 53 & 0 & 100 \\
\hline 5. & Weeding & 69 & 100 & 100 & 22 & 100 & 27 & 100 & 44 & 55 & 100 \\
\hline 6. & Harvesting & 47 & 100 & 93 & 87 & 100 & 20 & 100 & 50 & 89 & 11 \\
\hline 7. & Storage & 58 & 100 & 67 & 97 & 73 & 100 & 88 & 100 & 33 & 100 \\
\hline 8. & Transporting & 58 & 100 & 67 & 98 & 73 & 100 & 89 & 100 & 100 & 22 \\
\hline 9. & Marketing & 0 & 96 & 78 & 93 & 84 & 95 & 100 & 68 & 22 & 100 \\
\hline
\end{tabular}

M - Male; F - Female

manure for vegetables, fruits, cash crops and trees was mainly handled by women. Soil fertility of home garden is maintained by manure of livestock and kitchen waste and it is the responsibility of women (Galfato, 2011). Weeding was mainly done by family members including the husband, wife and children. The harvesting of home garden product was mainly done by men. The participation of women for harvesting was very low except for vegetables. Most of the products were stored by women. The reason for this is that the wives have experience in knowledge of the storage area and conditions suitable for different crops. Home consumption is the principal purpose of home gardening. Men participate more in selling of cash crop and root crops. While in the case of vegetables and fruits it is mainly done by women. Majority of women (58\%) were found to be involved in dead-branch collection and most men were involved in collection of fallen (53\%) and standing (58\%) trees. Women were found to be involved in all aspects of homestead production, from the selection of land to decisions regarding which crops to grow and to harvest. Women also cultivate horticultural crops for commercial purposes in their home gardens. Seed selection was performed by women. Families exchange seeds among themselves, usually at the time of fruit selection. Pests, low productivity, and poor fertility of seeds were the common problems expressed by women. Women believe that the remaining ash from different kinds of fuel like fuel wood and cow dung is sufficient for the growth of new crops. Mulching is carried out by women and men, using banana and papaya leaves. Women also have responsibility for pest control and use a simple indigenous remedy: application of ashes to plants infested by pests. 
Participation of Household Women in Undertaking Plant Health Management Practices in Home Gardens

\section{CONCLUSION}

The results of this study show that women play an important role in home garden management activities. Giving due respect to their indigenous knowledge and encouraging them in more home garden activities, and providing low interest credit facilities should be the priority of the government and NGOs. Women dominate in most of the subsistence crops and in small ruminant livestock production. Strengthening the extension services along with the provision of inputs such as improved seeds of vegetables and provision of fruit tree seedlings based on the preference of households is required. All these will play a significant role in raising the benefits ensuring food security and income.

\section{REFERENCES}

Abebe, T. \& Mulu, D. (2017). The Role of Women in the Management and Utilization of Home Garden: The Case of Dale District, in Southern Ethiopia. Asian Journal of Plant Science and Research, 7(4):41-54

Bajracharya, B. (1994). Gender Issues in Nepali Agriculture: A Review. C1994, (REP-7898. CIMMYT.).

Bunderson, T. W., El-Wakeel, A., Saad, Z. A., \& Hashim, I. (1990). Agroforestry practices and potentials in western Sudan. In: Planning for agroforestry. Selected contributions from an international symposium, Washington State University, Pullman, Washington, (24-27 April 1989). (pp. 227-246). Elsevier Science Publishers.

FAO. (2000). Gender and food security. Food and Agriculture Organization of the United Nations. Highlights. Women and Population Division. National Sectoral Report on Women in Pakistan. FAO, Rome

FAO. (2003). Gender and food security. Education, extension and communication. The uplift and empowerment of rural women in Pakistan. FAO, Rome

Galfato G. G. (2011). The role of women in home garden agroforestry system. Unpublished M.Sc. Thesis. Hawassa College of Agriculture, Hawassa, Ethiopia, pp. 67.

Khanal S. \& Khanal S. P. (2016). Assessment of women's role in management of home garden in Sorabhag V.D.C Morang, Nepal, Global Journal of Biology, Agriculture \& Health Sciences, 5 (2):124-128.

Ranjan S.K \& Hedija, M. (2004). Introspection in to rural women empowerment in Ethiopia, Paper published in National Education Seminar proceedings Bahir Dar University, Ethiopia 